[Article]

\title{
二氟沙星在中性水溶液中的光化学性质
}

\author{
李海霞 ${ }^{1,2}$ 周保昌 ${ }^{1}$ 刘艳成 ${ }^{1,2}$ 唐睿智 ${ }^{1,2}$ 张 鸠 ${ }^{1,2}$ 李景烨 ${ }^{1}$ 王文锋 ${ }^{1, *}$ \\ ('中国科学院上海应用物理研究所, 上海 201800; 2中国科学院大学, 北京 100049)
}

摘要: 对二氟沙星在中性水溶液中的光化学性质进行了研究. 在 $\mathrm{pH}$ 值为 7.17 的水溶液中二氟沙星的紫外吸 收峰位于 $273 \mathrm{~nm}$ (摩尔消光系数 $\left.\varepsilon=33000 \mathrm{dm}^{3} \cdot \mathrm{mol}^{-1} \cdot \mathrm{cm}^{-1}\right), 323 \mathrm{~nm}\left(\varepsilon=15500 \mathrm{dm}^{3} \cdot \mathrm{mol}^{-1} \cdot \mathrm{cm}^{-1}\right), 335 \mathrm{~nm}(\varepsilon=$ $15500 \mathrm{dm}^{3} \cdot \mathrm{mol}^{-1} \cdot \mathrm{cm}^{-1}$ ) 处. 荧光吸收和发射光谱均显示二氟沙星具有 $\mathrm{pH}$ 效应, 其 $\mathrm{pK}$ (电离平衡常数)测定分别 为 5.9 和 9.8. 二氟沙星的荧光量子产额较低, 在 $\mathrm{pH}=3.00$ 时达到最大值, 为 0.06 . 同时对二氟沙星在中性水溶 液中的激光光解和脉冲辐解进行详细研究. 激光光解研究发现在水溶液中二氟沙星的三重激发态位于 620 $\mathrm{nm}$, 其摩尔消光系数为 $7900 \mathrm{dm}^{3} \cdot \mathrm{mol}^{-1} \cdot \mathrm{cm}^{-1}$. 通过能量转移的方法得到其三重激发态的能量为 $263.5 \mathrm{~kJ} \cdot \mathrm{mol}^{-1}$, 三重激发态的量子产额为 0.21 . 在激光激发下, 二氟沙星进行单光子电离其量子产额为 0.02 . 脉冲辐解研究表 明二氟沙星可以与水合电子 $\left(\mathrm{e}_{\mathrm{aq}}^{-}\right)$及羟基自由基 $(\cdot \mathrm{OH})$ 快速反应, 其二级反应动力学常数分别为 $1.72 \times 10^{10}$ 和 $1.0 \times 10^{10} \mathrm{dm}^{3} \cdot \mathrm{mol}^{-1} \cdot \mathrm{s}^{-1}$. 本文对二氟沙星光化学性质的研究有助于确定其光敏毒性的产生机理.

关键词: 光化学性质; 激光光解; 脉冲辐解; 二氟沙星; 激发态

中图分类号: 0644

\section{Primary Photochemical Properties of Difloxacin in Neutral Aqueous Solution}

\author{
LI Hai-Xia ${ }^{1,2} \quad$ ZHOU Bao-Chang $\quad$ LIU Yan-Cheng ${ }^{1,2} \quad$ TANG Rui-Zhi' ${ }^{1,2}$ \\ ZHANG Peng ${ }^{1,2} \quad$ LI Jing-Ye ${ }^{1} \quad$ WANG Wen-Feng ${ }^{1, *}$ \\ ('Shanghai Institute of Applied Physics, Chinese Academy of Sciences, Shanghai 201800, P. R. China; \\ ${ }^{2}$ Graduate University of Chinese Academy of Sciences, Beijing 100049, P. R. China)
}

\begin{abstract}
The photochemical properties of difloxacin (DFX) were investigated in neutral aqueous solution. DFX aqueous solution showed intense absorption with one peak at $273 \mathrm{~nm}$ (molar absorption coefficient $\varepsilon=$ $\left.33000 \mathrm{dm}^{3} \cdot \mathrm{mol}^{-1} \cdot \mathrm{cm}^{-1}\right)$ and two other peaks at 323 and $335 \mathrm{~nm}\left(\varepsilon=15500 \mathrm{dm}^{3} \cdot \mathrm{mol}^{-1} \cdot \mathrm{cm}^{-1}\right)$ with the same molar absorption coefficient. Both the absorption and emission properties of DFX were $\mathrm{pH}$-dependent. The acid dissociation constant $\left(\mathrm{p} K_{\mathrm{a}}\right)$ for the protonation equilibria of the ground state (5.9 and 9.8) were determined spectroscopically. DFX fluoresces weakly, and its maximum quantum yield for fluorescence emission was 0.06 at $\mathrm{pH}$ 3. Laser flash photolysis and pulse radiolysis studies were carried out to characterize the transient species of DFX aqueous solution. Triplet-triplet absorption reached a maximum at $620 \mathrm{~nm}$ with a molar absorption coefficient of $7900 \mathrm{dm}^{3} \cdot \mathrm{mol}^{-1} \cdot \mathrm{cm}^{-1}$. The energy transfer method was used to estimate the triplet energy of DFX, which was $263.5 \mathrm{~kJ} \cdot \mathrm{mol}^{-1}$. The quantum yield of triplet formation was determined to be 0.21 . Furthermore, DFX showed monophotonic photoionization with a quantum yield of 0.02 . Pulse radiolysis indicated that DFX could react with $\mathrm{e}_{\mathrm{aq}}^{-}$and $\cdot \mathrm{OH}$, and the bimolecular rate constants for these reactions were $1.72 \times 10^{10}$ and $1.0 \times 10^{10} \mathrm{dm}^{3}$. $\mathrm{mol}^{-1} \cdot \mathrm{s}^{-1}$, respectively. It is expected that this research may be helpful in determining the phototoxicity mechanism of DFX.
\end{abstract}

Received: April 10, 2014; Revised: September 15, 2014; Published on Web: September 16, 2014.

"Corresponding author. Email: wangwenfeng@sinap.ac.cn; Tel: +86-21-39194953; Fax: +86-21-59553021.

The project was supported by the National Natural Science Foundation of China (21173252).

国家自然科学基金(21173252)资助项目 
Key Words: Photochemical property; Laser flash photolysis; Pulse radiolysis; Difloxacin; Excited state

\section{Introduction}

Fluoroquinolones (FQs) are successful antimicrobials which have been widely prescribed as antibiotics because of their optimal properties. However, occasionally adverse cutaneous reactions related to light exposure have been reported, such as dermatitis, in areas of skin exposed to sun light. FQs have been shown to induce efficiently the DNA cleavage as well as membrane photodamage. ${ }^{1,2}$ Furthermore they can also induce photoallergic response, due to the photohaptens and photocarcinogenic effects when they bind to proteins. ${ }^{3}$

The mechanism of phototoxicity can be via the production of ionic radicals, the photosensitization of singlet oxygen and other reactive oxygen species (ROS). ${ }^{4}$ The relationship among the structures of several FQ antibacterials, their activities and their side effects have been studied. Phototoxicity of FQs seems to particularly depend on the substituent in position $8,{ }^{5}$ increasing in the order: $-\mathrm{H}<-\mathrm{OCH}_{3}<-\mathrm{F},-\mathrm{Cl}$, which is related to its maximum concentration in serum. ${ }^{6,7}$ Structure also influences the photodegradation of FQs. This process usually involves loss of the fluoride in position 6 of the aromatic ring, the final product depending on the medium in which the reaction takes place. ${ }^{8}$ The efficiency of the $\mathrm{C}-\mathrm{F}$ bond cleavage is largely influenced by the substituent in position 8 , which determines the internal chargetransfer character of the excited state. The mechanism is considered to involve a nucleophilic attack on the carbon atom, which links to the fluoride. Thus, increasing electronegativity of this substituent makes the $\mathrm{C}-\mathrm{F}$ bond cleavage much easier, while electron-donating atoms prevent defluorination. According to this, defluorination is primary photodegradation process in enoxacin $(\mathrm{N})$, norfloxacin $(\mathrm{C}-\mathrm{H})$, and lomefloxacin $(\mathrm{C}-\mathrm{F}),{ }^{8}$ nevertheless it is less important in ofloxacin $(\mathrm{C}-\mathrm{OR})$ and does not occur in rufloxacin $(\mathrm{C}-\mathrm{SR}){ }^{1}$ Photoreactivity may be initiated from the excited singlet state, such as in the case of lomefloxacin, or from the triplet state, such as described for norfloxacin and enoxacin. ${ }^{9}$ Therefore, this research of the excited state may be helpful in determining the phototoxicity mechanism and photo-reactivity of difloxacin (DFX), and our team did a lot of work on the FQs about its photo-properties. ${ }^{10-12}$ Scheme 1 shows the structure of DFX.<smiles>CN1CCN(c2cc3c(cc2F)c(=O)c(C(=O)O)cn3-c2ccc(F)cc2)CC1</smiles>

Scheme 1 Structure of DFX
Difloxacin[6-fluoro-1-(4-fluorophenyl)-1,4-dihydro-7-(4methyl-1-piperazinyl)-4-oxo-3-quinolone carboxylic acid] belongs to the new class of FQs, which are applied in considerable amounts in large-scale husbandry, and especially in the infection therapy of chicken, dogs, and pigs. ${ }^{13-15}$ Similarly to that of other FQs, the bactericidal activity of DFX is mediated by inhibition of subunit A of DNA topoisomerases II (gyrase), ${ }^{16}$ which is an enzyme that is essential for DNA synthesis and repair. ${ }^{17}$ DFX is different from other FQs on account of its $p$-fluorophenyl ring at position N-1 of the quinoline nucleus, which gives it enhanced activity against Gram-positive bacteria. ${ }^{18}$ DFX is indicated for treatments of bovine respiratory disease caused by Pasteurella spp. and lor Mycoplasma spp. ${ }^{19}$ Although the pharmacokinetic and pharmacodynamic ${ }^{19}$ parameters of DFX have been investigated in a number of species, including humans, chickens, pigs, dogs, and goats, ${ }^{14,20-25}$ however, the photochemical behavior of DFX has not been adequately characterized in literature.

In this article, we present the steady-state and transient-state behaviors of DFX. Both the absorption and emission properties were researched by UV-Vis absorption spectra and fluorescence emission spectra. The primary photochemical properties of DFX were studied by laser flash photolysis and pulse radiolysis. Furthermore the quantum yields of photoionization and triplet state of DFX ( $\left.{ }^{3} \mathrm{DFX}^{*}\right)$ were also analyzed as well. All these results provide a theoretical foundation for the further study of the phototoxicity activity of FQs.

\section{Materials and methods}

\subsection{Materials}

High purity ( $>99.8 \%$ ) DFX was obtained from Sigma Chemicals and used as received. Phosphate salts (analysis reagent) were obtained from J\&K Chemical Ltd. All solutions were prepared freshly with ultrapure water which was provided by a Millipore purification system.

\subsection{Methods}

UV-Visible (UV-Vis) absorbance was measured on model U3900/3900H spectrophotometer (Hitachi High-Technologies Corporation). Fluorescence signals were measured on model F4500 luminescence spectrometer (Hitachi High-Technologies Corporation). Fluorescence quantum yield $\left(\Phi_{\mathrm{F}}\right)$ was determined by comparison with quinine bisulfate in $0.05 \mathrm{~mol} \cdot \mathrm{L}^{-1}$ sulfuric acid $\left(\Phi_{\mathrm{F}}=0.56^{26}\right)$ as a standard. Aqueous solution of DFX $\left(4.6 \times 10^{-5} \mathrm{~mol} \cdot\right.$ $\mathrm{L}^{-1}$ ) was prepared and $0.1 \mathrm{~mol} \cdot \mathrm{L}^{-1} \mathrm{KCl}$ was added in order to keep the ionic strength constant during the titration. The $\mathrm{pH}$ value of the solution was modified by adding drops of concentrated $\mathrm{HCl}$ or $\mathrm{NaOH}$ aqueous solution, under continuous stirring, $\mathrm{pH}$ value was constantly monitored using a glass electrode and the absorption was measured immediately after each addition. The titration curves were fitted using a sigmoidal function and analyzed by nonlinear least square methods. The $\mathrm{p} K_{\mathrm{a}}$ values were deter- 
mined from the half-height of the titration curve.

Laser flash photolysis (LFP) experiments were carried out at the Shanghai Institute of Applied Physics using Nd:YAG laser. Nd: YAG laser provided a $355 \mathrm{~nm}$ pulse with duration of $5 \mathrm{~ns}$ and the maximum energy of $240 \mathrm{~mJ}$ per pulse was used as the pump light source. A Xenon lamp was employed as detecting light source. The laser and the analyzing light beam passed perpendicularly through a quartz cell. The transmitted light entered a monochromator equipped with an R955 photomultiplier. The output signal from the HP54510B digital oscillograph was transferred to a personal computer for further analysis. The LFP setup has been previously described. ${ }^{27}$ All experiments were performed in water solution. Samples were bubbled with high-purity $(99.999 \%) \mathrm{N}_{2}$, $\mathrm{N}_{2} \mathrm{O}$, or $\mathrm{O}_{2}(99.999 \%)$ for at least $20 \mathrm{~min}$, before photolysis experiments were initiated.

Pulse radiolysis experiments were performed utilizing a 10 $\mathrm{MeV}$ linear accelerator which delivers an electron pulse with duration of $10 \mathrm{~ns}$. The dosimetry of electron pulse was determined by thiocyanate dosimeter using yield $G\left[(\mathrm{SCN})_{2}^{-} \cdot\right]=5.8$ in $1 \times 10^{-4}$ $\mathrm{mol} \cdot \mathrm{L}^{-1} \mathrm{KSCN}$ solution saturated with $\mathrm{N}_{2} \mathrm{O}$ by taking the molar absorption coefficient $\varepsilon_{480 \mathrm{~mm}}=7600 \mathrm{dm}^{3} \cdot \mathrm{mol}^{-1} \cdot \mathrm{cm}^{-1}$ for $(\mathrm{SCN})_{2}^{-} \cdot$ The details of the setup and operation conditions were given in the previous paper. ${ }^{28}$ The dose per electron pulse was $10 \mathrm{~Gy}$.

\section{Results and discussion}

\subsection{Absorption and emission properties}

The UV-Vis absorption spectra of DFX at $\mathrm{pH} 7.17$ showed two bands. One was a sharp band at $273 \mathrm{~nm}$ with $\varepsilon$ of $33000 \mathrm{dm}^{3} \cdot \mathrm{mol}^{-1}$. $\mathrm{cm}^{-1}$. The other one was a less intense, broader band with two peaks at 323 and $336 \mathrm{~nm}$, a long tail extending to $360 \mathrm{~nm}$ (Fig.1), they have the same molar absorption coefficients of $15500 \mathrm{dm}^{3}$. $\mathrm{mol}^{-1} \cdot \mathrm{cm}^{-1}$. Similar values have been reported for other FQs. ${ }^{29-32}$ The absorption spectra did not show any significant variations when the $\mathrm{pH}$ value was raised from 5.70 to 13.00 . However, acidification of the medium had a stronger influence on the absorption properties of DFX. When the $\mathrm{pH}$ value rises from 3.00 to 7.00 , the main absorption band was red-shifted by $8 \mathrm{~nm}$ and its intensity increased. At the same time, the smaller peaks at 323 and $336 \mathrm{~nm}$ were blue-shifted by 7 and $5 \mathrm{~nm}$, respectively. At the meantime, their intensity decreased while the tail extended to 380 $\mathrm{nm}$. The plot of the maximum absorption wavelength against $\mathrm{pH}$ (inset of Fig.1) can be fitted to two sigmoidal curves, from which $\mathrm{p} K_{\mathrm{a}}$ values of $5.91 \pm 0.02$ and $9.89 \pm 0.02$ can be deduced corre-

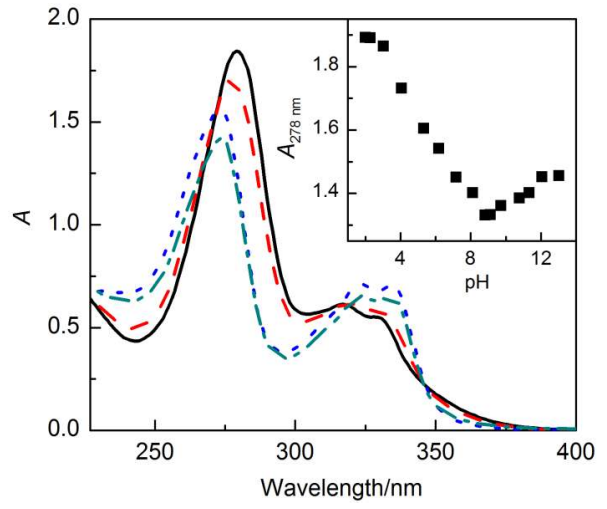

Fig.1 UV-Vis absorption spectra of DFX in aqueous solution at different pH values of $3.03(-), 3.30(--)$,

$$
7.17(\cdots \cdots), 13.40(-\cdot-)
$$

The inset shows the variation of $278 \mathrm{~nm}$ absorption against $\mathrm{pH}$ values.

sponding to the $\mathrm{p} K_{\mathrm{a}}$ for the dissociation of the carboxylic and the amino groups of the molecule, respectively. Thus, at neutral $\mathrm{pH}$ the predominant structure is a zwitterion. This process was also observed in other FQs ${ }^{29-32}$ which is depicted in Scheme 2.

When the DFX was excited at $355 \mathrm{~nm}$ with $\mathrm{pH}$ of 7.17, a broad band around $465 \mathrm{~nm}$ was presented with a considerably large stoke shift. This shift has been previously observed in other FQs. ${ }^{29-32}$ It can be explained by the presence of both an electron-donating amino group and an electron-withdrawing $\mathrm{F}$ substituent, which causes the $\pi \rightarrow \pi^{*}$ excited state to possess an internal charge-transfer character. ${ }^{33}$ Both the intensity and the maximum wavelength of the emission bands were found to be $\mathrm{pH}$-dependent (Fig.2). The emission maximum wavelength showed a blue-shift from $465 \mathrm{~nm}$ at $\mathrm{pH} 3.00$ to around $455 \mathrm{~nm}$ at $\mathrm{pH} 5.70$. The maximum fluorescence yield was 0.06 at around $\mathrm{pH} 3.00$, and the yield was decreased as the $\mathrm{pH}$ of the medium lowered. Similar behavior was observed as the medium became more basic, with the fluorescence yield dropping to approximately zero above $\mathrm{pH} 11.00$. This reduction of fluorescence emission in basic medium has been previously observed in other FQs with a piperazinyl substituent on position-7. Deprotonation of the N-4' at high $\mathrm{pH}$ has been suggested to be responsible for this effect. It renders the lone pair of electrons on the nitrogen atom available to participate in an intramolecular electron transfer to the FQ main system. ${ }^{34}$ So a very efficient pathway is hence established for the deactivation of the singlet excited state. It seems that this effect only occurs with the piperazinyl group, such as ciprofloxacin, ofloxacin, and lome-<smiles>C[N+]1(C)CCN(c2cc3c(cc2F)c(=O)c(C(=O)O)cn3-c2ccc(F)cc2)CC1</smiles>

cation form<smiles>C[N+]1(C)CCN(c2cc3c(cc2F)c(=O)c(C(=O)[O-])cn3-c2ccc(F)cc2)CC1</smiles>

zwitterionic form<smiles>CN1CCN(c2cc3c(cc2F)c(=O)c(C(=O)O)cn3-c2ccc(F)cc2)CC1</smiles>

Scheme 2 Equilibrium between protonated forms of DFX 


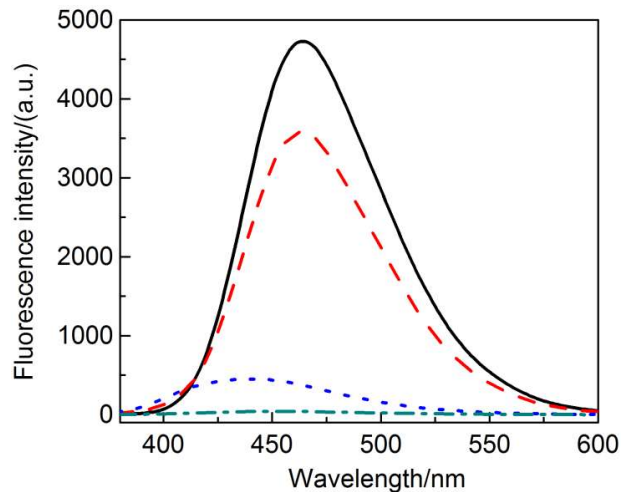

Fig.2 Fluorescence emission spectra of DFX in aqueous solution at different $\mathrm{pH}$ values of $3.03(-), 5.33(--)$,

$$
7.17(\cdots \cdots), 10.78(-\cdot-)
$$

floxacin. Nevertheless, FQs with different substituents in position7 do not show this effect such as moxifloxacin. ${ }^{32}$

\subsection{Laser flash photolysis}

\subsubsection{Transient spectra}

The transient absorption spectra of a nitrogen saturated $1 \times 10^{-4}$ $\mathrm{mol} \cdot \mathrm{L}^{-1}$ aqueous solution of DFX at $\mathrm{pH} 7.17$ after excitation by $355 \mathrm{~nm}$ laser pulse showed absorption in both short and long wavelength regions (Fig.3). The long wavelength band (centered at $720 \mathrm{~nm}$ ) completely decayed within $3 \mu \mathrm{s}$, with a first-order rate of $1.5 \times 10^{6} \mathrm{~s}^{-1}$ (inset of Fig.3). When a nitrous oxide saturated solution was employed, the absorption band around $720 \mathrm{~nm}$ was no longer observed, while the shorter wavelength absorption bands remain unaffected. Based on this fact, the fast-decaying absorption at $720 \mathrm{~nm}$ can reasonably be assigned to the hydrated electron, formed according to reaction (2). This hydrated electron ( $\mathrm{e}_{\mathrm{aq}}^{-}$) can be scavenged by $\mathrm{N}_{2} \mathrm{O}$ as described by reaction (4). ${ }^{35}$

$\mathrm{DFX}+h v{ }^{1} \mathrm{DFX}^{*}$

${ }^{1} \mathrm{DFX}^{*} \rightarrow \mathrm{DFX}^{+}+\mathrm{e}_{\text {aq }}^{-}$

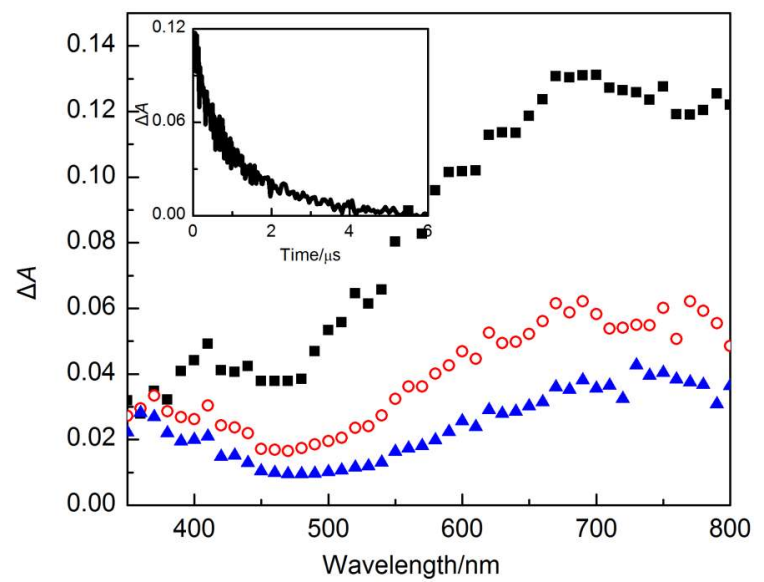

Fig.3 Transient difference absorption spectra observed at $100 \mathrm{~ns}$

(-ø-), $1 \mu \mathrm{s}(-\circ-), 2 \mu \mathrm{s}(-\Delta-)$ after subjecting a nitrogen saturated aqueous solution of $1 \times 10^{-4} \mathrm{~mol} \cdot \mathrm{L}^{-1} \mathrm{DFX}$ in $2 \times 10^{-3} \mathrm{~mol} \cdot \mathrm{L}^{-1}$ phosphate buffer (pH 7.17) to $8 \mathrm{~mJ}$ of $355 \mathrm{~nm}$ laser pulse Inset shows the decay profiles of the signal at $720 \mathrm{~nm}$ obtained after laser excitation of $1 \times 10^{-4} \mathrm{~mol} \cdot \mathrm{L}^{-1} \mathrm{DFX}$ aqueous solution.
${ }^{1} \mathrm{DFX}^{*} \rightarrow{ }^{3} \mathrm{DFX}^{*}$

$\mathrm{e}_{\text {aq }}^{-}+\mathrm{N}_{2} \mathrm{O} \rightarrow \mathrm{N}_{2}+\cdot \mathrm{OH}+\mathrm{OH}^{-}$

As shown in Fig.4, the transient absorption of DFX aqueous solution which was saturated by nitrous oxide was determined at different times after the laser pulse. The end of pulse spectrum showed a band centered at $620 \mathrm{~nm}$ which decayed with a firstorder rate of $7.69 \times 10^{5} \mathrm{~s}^{-1}$, the decay of the transient was found to increase to be $3.32 \times 10^{6} \mathrm{~s}^{-1}$ in the presence of oxygen. On the basis of this, the transient band at $620 \mathrm{~nm}$ was tentatively assigned to the triplet state of DFX. The assignment was confirmed by energy transfer experiments (Fig.5).

As shown in Fig.5 the transient spectra obtained at different times after subjecting nitrogen saturated aqueous solution of DFX $\left(1.5 \times 10^{-4} \mathrm{~mol} \cdot \mathrm{L}^{-1}\right)$ containing $1.5 \times 10^{-3} \mathrm{~mol} \cdot \mathrm{L}^{-1}$ naproxen $(\mathrm{NAP})$ to $355 \mathrm{~nm}$ laser pulse. NAP has not UV-Vis absorption at $355 \mathrm{~nm}$, so all the incident laser light was absorbed by DFX. The initial spectrum was similar to that seen in Fig.4. It could be observed from the Fig. 5 that a peak at $620 \mathrm{~nm}$ appeared instantly after the laser flash photolysis. As the decay in $620 \mathrm{~nm}$, there was a peak at $430 \mathrm{~nm}$. This transient absorption was the characteristic absorption of the triplet state of NAP $\left({ }^{3} \mathrm{NAP}^{*}\right) .{ }^{36}$ In the absence of NAP, the triplet state of DFX decayed with a first-order rate constant of $7.69 \times 10^{5} \mathrm{~s}^{-1}$, whereas the rate constant increased to $5.87 \times 10^{6} \mathrm{~s}^{-1}$ in the presence of $1.5 \times 10^{-3} \mathrm{~mol} \cdot \mathrm{L}^{-1} \mathrm{NAP}$ and a similar rate constant was observed for the build-up at $430 \mathrm{~nm}$. So it could conclude that the putative triplet state of DFX was quenched by NAP (the triplet energy $\left.\left(E_{\mathrm{T}}\right)=259 \mathrm{~kJ} \cdot \mathrm{mol}^{-1}\right)^{36}$ to form the triplet state of NAP. This confirms the energy transfer from the ${ }^{3} \mathrm{DFX}^{*}$ to ${ }^{3} \mathrm{NAP}^{*}$ in accordance with reaction (5).

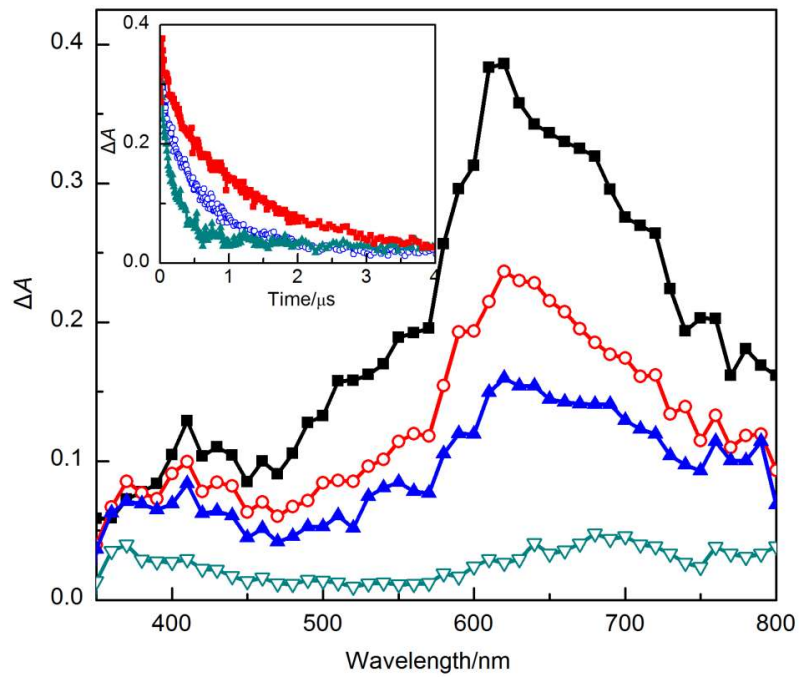

Fig.4 Transient difference absorption spectra observed at $100 \mathrm{~ns}$

(-ø-), $500 \mathrm{~ns}(-\circ-), 1 \mu \mathrm{s}(-\Delta-), 3 \mu \mathrm{s}(-\nabla-)$ after subjecting a nitrous oxide saturated aqueous solution of $1.5 \times 10^{-4} \mathrm{~mol} \cdot \mathrm{L}^{-1}$ DFX in $2 \times 10^{-3} \mathrm{~mol} \cdot \mathrm{L}^{-1}$ phosphate buffer (pH 7.17) to $8 \mathrm{~mJ}$ of $355 \mathrm{~nm}$ laser pulse

Inset shows the decay profiles of the signal at $620 \mathrm{~nm}$ obtained after laser excitation of DFX aqueous solutions of $1.5 \times 10^{-4} \mathrm{~mol} \cdot \mathrm{L}^{-1}$ saturated with $\mathrm{N}_{2}(-\mathbf{-}-)$, air (-O-), and $\mathrm{O}_{2}(-\mathbf{\Delta}-)$. 


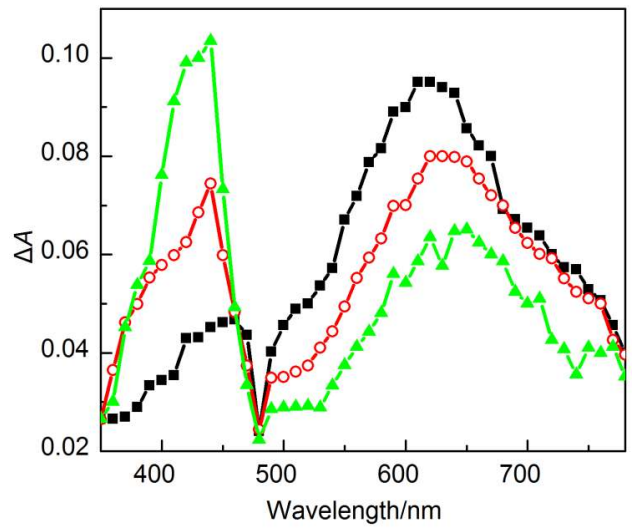

Fig.5 Transient absorption spectra at $0.01 \mu$ s (-匹-), $0.1 \mu$ s (-०-), 1 $\mu \mathrm{s}(-\Delta-)$ after subjecting a nitrogen saturated aqueous solution

of $1.5 \times 10^{-4} \mathrm{~mol} \cdot \mathrm{L}^{-1} \mathrm{DFX}$ containing $1.5 \times 10^{-3} \mathrm{~mol} \cdot \mathrm{L}^{-1}$ naproxen in $2 \times 10^{-3} \mathrm{~mol} \cdot \mathrm{L}^{-1}$ phosphate buffer (pH 7.17) to $8 \mathrm{~mJ}$ of $355 \mathrm{~nm}$ laser pulse

${ }^{3} \mathrm{DFX}^{*}+\mathrm{NAP} \rightarrow{ }^{3} \mathrm{NAP}^{*}+\mathrm{DFX}$

3.2.2 Determination of triplet energy and molar absorption coefficient of ${ }^{3} \mathrm{DFX}$

\subsubsection{Triplet energy of ${ }^{3} \mathrm{DFX}$}

In order to determine $E_{\mathrm{T}}$ of ${ }^{3} \mathrm{DFX}$, energy transfer quenching of the T-T signal by NAP acceptor was investigated. The triplet energy of NAP was known to be $259 \mathrm{~kJ} \cdot \mathrm{mol}^{-1}$ and its maximum absorption spectral wavelength was observed at $430 \mathrm{~nm}$. The rate constant for energy $\left(k_{\mathrm{ET}}\right)$ between ${ }^{3} \mathrm{DFX}^{*}$ and ${ }^{3} \mathrm{NAP}^{*}$ (reaction (5)) depended only on the triplet energy gap $\left(\Delta E_{\mathrm{T}}\right)$. Assuming that it corresponds to vertical transfer which obeys the Sandros equation ${ }^{37,38}$ (equation (6)), where $k_{\mathrm{D}}$ is the rate constant for diffusion $\left(k_{\mathrm{D}}=1.5 \times\right.$ $\left.10^{10} \mathrm{dm}^{3} \cdot \mathrm{mol}^{-1} \cdot \mathrm{s}^{-1}\right){ }^{39}$

$$
k_{\mathrm{ET}}=k_{\mathrm{D}} \times \exp \left(-\Delta E_{\mathrm{T}} / R T\right)
$$

As shown in Fig.5 the energy transfer reaction happened from ${ }^{3} \mathrm{DFX}^{*}$ to NAP, and then formed ${ }^{3} \mathrm{NAP}^{*}$. At the end of the pulse, the triplet absorption of DFX at $620 \mathrm{~nm}$ was observed. As the decay of ${ }^{3} \mathrm{DFX}^{*}$, a new absorption centering on $430 \mathrm{~nm}$ appeared, which was assigned to be ${ }^{3} \mathrm{NAP}^{*}$ absorption. The $k_{\mathrm{ET}}$ was determined by the slope (inset of Fig.6) as $2.5 \times 10^{9} \mathrm{dm}^{3} \cdot \mathrm{mol}^{-1} \cdot \mathrm{s}^{-1}$. Therefore the triplet energy gap $\Delta E_{\mathrm{T}}$ and the triplet energy of ${ }^{3} \mathrm{DFX}^{*}$ could be estimated as 4.5 and $263.5 \mathrm{~kJ} \cdot \mathrm{mol}^{-1}$, respectively.

\subsubsection{Molar absorption coefficient of ${ }^{3} \mathrm{DFX}{ }^{*}\left(\varepsilon_{620 \mathrm{~nm}}\right)$}

In this experiment $1.5 \times 10^{-4} \mathrm{~mol} \cdot \mathrm{L}^{-1}$ nitrogen saturated aqueous solutions of DFX which containing different concentrations of NAP were subject to $355 \mathrm{~nm}$ laser excitation. The decay of absorption at $620 \mathrm{~nm}$ and build-up at $430 \mathrm{~nm}$ were measured. The typical traces were shown in Fig.6. From a plot of the decay rate constant at $620 \mathrm{~nm}$ against the concentration of NAP, the bimolecular rate constant for the energy transfer reaction (5) was calculated to be $2.5 \times 10^{9} \mathrm{dm}^{3} \cdot \mathrm{mol}^{-1} \cdot \mathrm{s}^{-1}$. If all DFX triplets were to sensitize the formation of NAP triplet then $\left[{ }^{3} \mathrm{DFX}{ }^{*}\right]=\left[{ }^{3} \mathrm{NAP}^{*}\right]$. However, at any given concentration of NAP, only a fraction of ${ }^{3} \mathrm{DFX}^{*}$ sensitizes the formation of ${ }^{3} \mathrm{NAP}^{*}$ and this fraction is given by $\left(k_{1}-k_{0}\right) / k_{1}$, where $k_{0}$ and $k_{1}$ are the rate constants for the decay in the absence and presence of NAP.

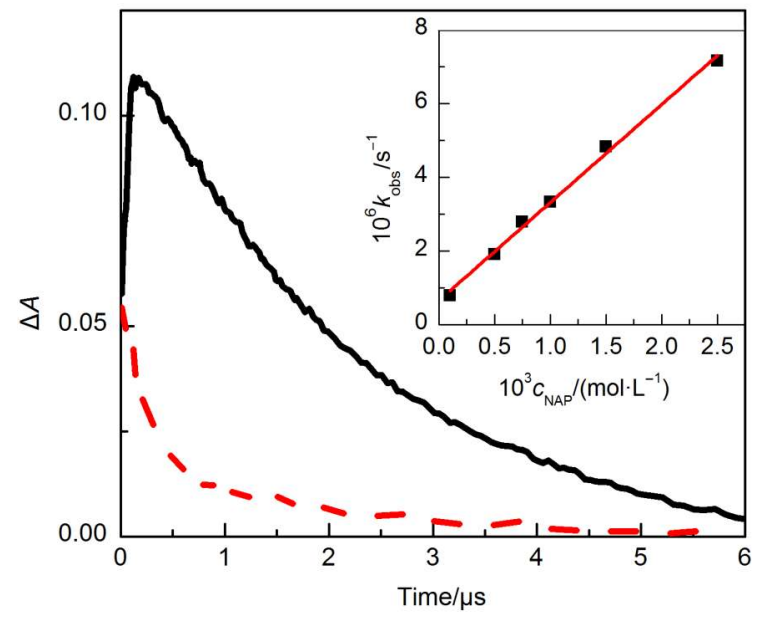

Fig.6 Decay and growth profiles monitored at $620 \mathrm{~nm} \mathrm{(-)} \mathrm{and}$ $430 \mathrm{~nm}(---)$ in nitrogen saturated solution of $1.5 \times 10^{-4} \mathrm{~mol} \cdot \mathrm{L}^{-1}$ DFX and $1.5 \times 10^{-3} \mathrm{~mol} \cdot \mathrm{L}^{-1} \mathrm{NAP}$

Inset shows the plot of the observed rates of DFX with naproxen as a function of naproxen concentrations.

Hence

$$
\left(k_{1}-k_{0}\right) \times\left[{ }^{3} \mathrm{DFX}^{*}\right]=\left[{ }^{3} \mathrm{NAP}{ }^{*}\right] \times k_{1}
$$

The absorbance of DFX at $620 \mathrm{~nm}$ after the end of the pulse and the absorbance of NAP at $430 \mathrm{~nm}$ after the end of reaction (5) could be measured. So the molar absorption coefficient of ${ }^{3} \mathrm{DFX}$ could be calculated using Equation (8).

$$
\varepsilon_{620 \mathrm{~nm}}=\varepsilon_{430 \mathrm{~nm}} \frac{k_{1}-k_{0}}{k_{1}} \frac{A_{620 \mathrm{~mm}}}{A_{430 \mathrm{~mm}}}
$$

Using a value of $9500 \mathrm{dm}^{3} \cdot \mathrm{mol}^{-1} \cdot \mathrm{cm}^{-1}$ for $\varepsilon_{430 \mathrm{~nm}},{ }^{36}$ the molar absorption coefficient of ${ }^{3} \mathrm{DFX}^{*}$ at $620 \mathrm{~nm}$ was calculated to be $7900 \mathrm{dm}^{3} \cdot \mathrm{mol}^{-1} \cdot \mathrm{cm}^{-1}$. This value was much higher than that reported for some other FQs ${ }^{40}$ with similar structure.

\subsubsection{Determination of quantum yields}

\subsubsection{Photoionization}

Further experiments were performed to quantify the extent of photoionization in DFX. A de-aerated aqueous solution of DFX and an acetonitrile solution of benzophenone (BEN) were excited using laser pulse of different intensities, both with identical absorbance at $355 \mathrm{~nm}$. The transient absorptions at 720 and $520 \mathrm{~nm}$ were measured in different conditions. Sodium hydrogen carbonate was used to keep the $\mathrm{pH}$ neutral instead of more common phosphate to avoid the strong reducing action of phosphate salts on the triplet state. The absorption changes at $720 \mathrm{~nm}\left(\Delta A_{720 \mathrm{~mm}}\right)$ were measured at increasing laser pulse energy in samples deaerated by bubbling $\mathrm{N}_{2}$, and the absorption changes at $520 \mathrm{~nm}$ $\left(\triangle A_{520} \mathrm{~nm}\right)$ were also measured at increasing laser pulse energy $(E)$ in samples de-aerated by bubbling $\mathrm{N}_{2}$. Straight lines were obtained in both cases (Fig.7), indicating that the photoionization process in DFX was monophotonic. These results were accorded with that of moxifloxacin ${ }^{32}$ and ofloxacin ${ }^{26,41}$. This is in contrast with some other FQs ${ }^{42}$ whose photoionization was found to be biphotonic. From the slopes of the two lines, and using the literature values for the triplet yield of benzophenone $\left({ }^{\mathrm{BEN}} \Phi_{\mathrm{isc}}=1\right.$, isc: inter-system crossing) with respective molar absorption coefficients $(\varepsilon=6500$ 


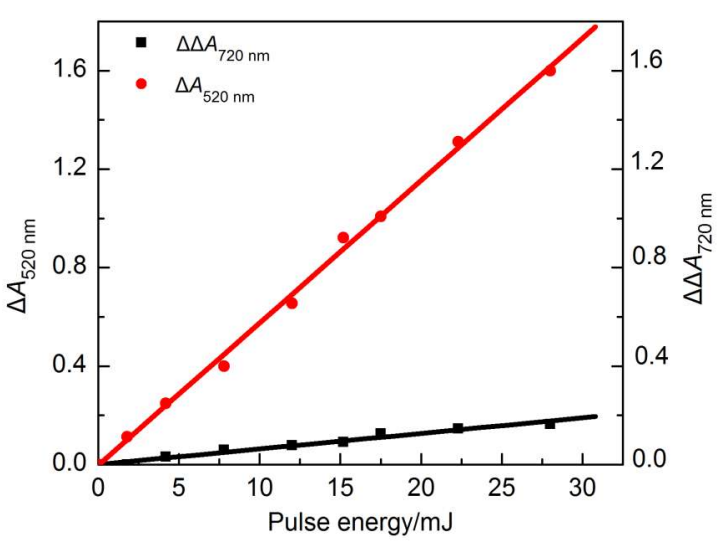

Fig.7 Plots of the end pulse absorption at $520 \mathrm{~nm}\left(\Delta A_{520} \mathrm{~nm}\right)$ in nitrogen saturated aqueous solution of BEN (10 $\mathrm{ns}$ after the pulse) and the solvated electron absorption at $720 \mathrm{~nm}\left(\Delta \Delta A_{720 \mathrm{~mm}}\right)$ in aqueous solution of DFX (10 ns after the pulse) obtained as the difference between the $\Delta A_{720 \mathrm{~nm}}$ in $\mathrm{N}_{2}$ and $\mathrm{N}_{2} \mathrm{O}$ against laser energy

$\mathrm{dm}^{3} \cdot \mathrm{mol}^{-1} \cdot \mathrm{cm}^{-1}$ at $\left.520 \mathrm{~nm}^{43}\right)$ and the molar absorption coefficient for the hydrated electron $\left(\varepsilon=17500 \mathrm{dm}^{3} \cdot \mathrm{mol}^{-1} \cdot \mathrm{cm}^{-1}\right.$ at $\left.720 \mathrm{~nm}^{35}\right)$, the quantum yield of DFX ( $\left.{ }^{\mathrm{DFX}} \Phi_{\mathrm{e}^{-}}\right)$for the photoionization process was calculated to be 0.022 using equation (9).

$$
{ }^{\mathrm{DFX}} \Phi_{\mathrm{e}^{-}}=\frac{\text { slope }_{\mathrm{DFX}}}{\text { slope }_{\mathrm{BEN}}} \times \frac{\varepsilon_{\mathrm{BEN}, 520 \mathrm{~nm}}}{\varepsilon_{\mathrm{DFX}, 720 \mathrm{~nm}}} \times{ }^{\mathrm{BEN}} \Phi_{\text {isc }}
$$

\subsubsection{Triplet state of DFX}

A de-aerated aqueous solution of DFX and an acetonitrile solution of BEN were excited using laser pulse of different intensities, both with identical absorbance at $355 \mathrm{~nm}$. Sodium hydrogen carbonate was also used to keep the $\mathrm{pH}$ neutral instead of more common phosphate to avoid the strong reducing action of phosphate salts on the triplet state. The transient absorption changes at $620 \mathrm{~nm}\left(\Delta A_{620} \mathrm{~mm}\right)$ and $520 \mathrm{~nm}\left(\Delta A_{520 \mathrm{~nm}}\right)$ were measured at increasing laser pulse energy $E$ in samples de-aerated by bubbling $\mathrm{N}_{2}$. Straight lines were obtained (Fig.8) and from the slopes of two lines and using the literature values for the triplet yield of BEN $\left({ }^{\mathrm{BEN}} \Phi_{\mathrm{isc}}=1\right)$ with respective molar absorption coefficients $(\varepsilon=6500$ $\mathrm{dm}^{3} \cdot \mathrm{mol}^{-1} \cdot \mathrm{cm}^{-1}$ at $\left.520 \mathrm{~nm}^{43}\right)$ and the molar absorption coefficient for ${ }^{3} \operatorname{DFX}^{*}\left(\varepsilon_{620 \mathrm{~mm}}=7900 \mathrm{dm}^{3} \cdot \mathrm{mol}^{-1} \cdot \mathrm{cm}^{-1}\right.$, from previous section), a value of 0.21 was obtained for ${ }^{\mathrm{DFX}} \Phi_{\text {isc }}$ using equation (10).

$$
{ }^{\mathrm{DFX}} \Phi_{\mathrm{isc}}=\frac{\text { slope }_{\mathrm{DFX}}}{\text { slope }_{\mathrm{BEN}}} \times \frac{\varepsilon_{\mathrm{BEN}, 520 \mathrm{~nm}}}{\varepsilon_{\mathrm{DFX}, 620 \mathrm{~mm}}} \times{ }^{\mathrm{BEN}} \Phi_{\text {isc }}
$$

\subsection{Pulse radiolysis}

\subsubsection{Reaction of DFX with $\mathrm{e}_{\mathrm{aq}}^{-}$}

The reaction of DFX with the reducing species hydrated electron $\mathrm{e}_{\mathrm{aq}}^{-}$was investigated. As shown in Fig.9, the transient absorption spectra were obtained by pulse radiolysis of the nitrogen-saturated solution containing $1.0 \times 10^{-4} \mathrm{~mol} \cdot \mathrm{L}^{-1} \mathrm{DFX}$ in the presence of $1 \%$ tert-butanol in $5 \times 10^{-3} \mathrm{~mol} \cdot \mathrm{L}^{-1}$ phosphate buffer at $\mathrm{pH}$ 7.17. tert-butanol was used to scavenge $\cdot \mathrm{OH}$ produced by water radiolysis, but $\mathrm{e}_{\mathrm{aq}}^{-}$was remained. In the absence of DFX, the absorption due to $\mathrm{e}_{\mathrm{aq}}^{-}$decayed with a first-order rate of $4.4 \times 10^{5} \mathrm{~s}^{-1}$, however this rate increased to $2.4 \times 10^{6} \mathrm{~s}^{-1}$ in the presence of $1.0 \times$ $10^{-4} \mathrm{~mol} \cdot \mathrm{L}^{-1} \mathrm{DFX}$. Considering that the signal-to-noise ratio at $640 \mathrm{~nm}$ was better than that at $720 \mathrm{~nm}$, the reactivity of $\mathrm{e}_{\mathrm{aq}}^{-}$with

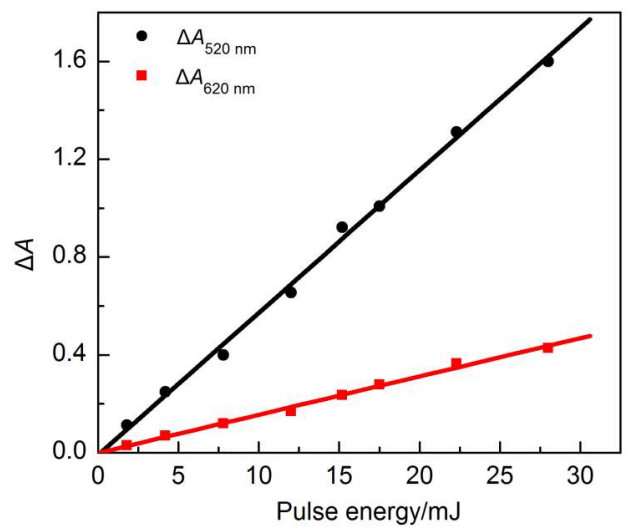

Fig.8 Plots of the end absorption at $520 \mathrm{~nm}\left(\Delta A_{520} \mathrm{~nm}\right)$ in nitrogen saturated aqueous solution of BEN (10 $\mathrm{ns}$ after the pulse) and the end absorption at $620 \mathrm{~nm}\left(\Delta A_{620} \mathrm{~mm}\right)$ in nitrogen saturated aqueous solution of DFX (10 ns after the pulse) against laser energy

DFX was investigated according to the pseudo-first-order decay kinetics of $\mathrm{e}_{\mathrm{aq}}^{-}$observed at $640 \mathrm{~nm}$ with the DFX concentrations range from the 0 to $1.0 \times 10^{-3} \mathrm{~mol} \cdot \mathrm{L}^{-1}$. This suggested that $\mathrm{e}_{\mathrm{aq}}^{-}$reacted very efficiently with ground state of DFX in a diffusioncontrolled manner with a bimolecular rate constant of $1.72 \times 10^{10}$ $\mathrm{dm}^{3} \cdot \mathrm{mol}^{-1} \cdot \mathrm{s}^{-1}$. The transient absorption spectrum of a DFX solution under these conditions showed a band centered at $380 \mathrm{~nm}$ (Fig.9). This band was assigned to the anion radical (protonated or deprotonated form) of DFX $\left(\mathrm{DFX}^{-}\right)$. The molar absorption coefficient of DFX ${ }^{-}$was calculated to be $\varepsilon_{380 \mathrm{~mm}}=1700 \mathrm{dm}^{3} \cdot \mathrm{mol}^{-1} \cdot \mathrm{cm}^{-1}$ using equation (12) with the corresponding values for:

$\mathrm{DFX}+\mathrm{e}_{\mathrm{aq}}^{-} \rightarrow \mathrm{DFX}^{-\bullet}$

$$
\varepsilon_{380 \mathrm{~nm}}=\varepsilon_{720 \mathrm{~nm}} \frac{k_{1}}{k_{1}-k_{0}} \frac{A_{380 \mathrm{~mm}}}{A_{720 \mathrm{~mm}}}
$$

where $k_{0}=4.1 \times 10^{5} \mathrm{~s}^{-1}$ and $k_{1}=2.9 \times 10^{6} \mathrm{~s}^{-1}$ are the decay rates of $\mathrm{e}_{\mathrm{aq}}^{-}$

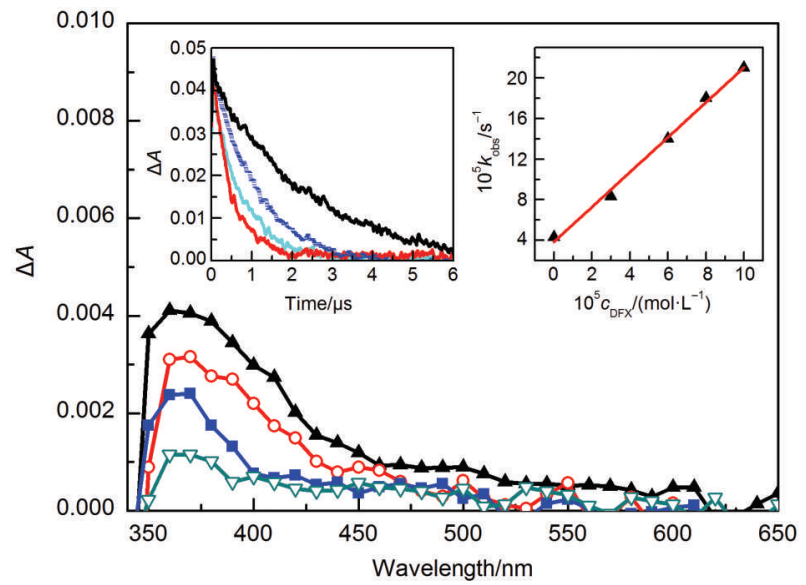

Fig.9 Transient difference absorption spectra observed at $4 \mu \mathrm{s}$ (- - -), $6 \mu \mathrm{s}(-\circ-), 15 \mu \mathrm{s}(-\square-), 20 \mu \mathrm{s}(-\nabla-)$ after pulse radiolysis of a $1.0 \times 10^{-4} \mathrm{~mol} \cdot \mathrm{L}^{-1} \mathrm{DFX}$ solution in $5 \times 10^{-3} \mathrm{~mol} \cdot \mathrm{L}^{-1}$ phosphate buffer (pH 7.17) which contained $1 \%$ tert-butanol and nitrogen saturated aqueous

Inset (left) shows the decay of $\mathrm{e}_{\mathrm{aq}}^{-}$at $640 \mathrm{~nm}$ in the presence of different DFX concentration from 0 to $1.0 \times 10^{-3} \mathrm{~mol} \cdot \mathrm{L}^{-1}$. Inset (right) shows the dependence of e ecay rate constant $\left(k_{\mathrm{obs}}\right)$ determined at $640 \mathrm{~nm}$ with different initial concentrations of DFX from 0 to $8 \times 10^{-4} \mathrm{~mol} \cdot \mathrm{L}^{-1}$. 
(720 $\mathrm{nm}$ absorption) in the absence and presence of DFX $\left(\varepsilon_{720 \mathrm{~mm}}=\right.$ $\left.17500 \mathrm{dm}^{3} \cdot \mathrm{mol}^{-1} \cdot \mathrm{cm}^{-135}\right)$.

$$
\begin{aligned}
& \text { 3.3.2 Reactions of DFX with } \cdot \mathrm{OH} \\
& \mathrm{DFX}+\cdot \mathrm{OH}^{\rightarrow} \mathrm{DFX}^{+}+\mathrm{OH}^{-} \\
& \mathrm{DFX}+\cdot \mathrm{OH} \rightarrow \mathrm{DFX}-\mathrm{OH} \cdot \\
& \mathrm{DFX}+\cdot \mathrm{OH} \rightarrow \mathrm{DFX}(-\mathrm{H}) \cdot+\mathrm{H}_{2} \mathrm{O}
\end{aligned}
$$

Hydroxyl radical $(\cdot \mathrm{OH})$ is the most reactive species produced in biological systems, causing oxidize damage to DNA, amino acid, proteins, and membrane lipids. As shown in Fig.10 reaction of DFX with $\cdot \mathrm{OH}$ at $\mathrm{pH} 7.17$ has produced a broad band with a shoulder and could not determine the $\lambda_{\max }$, due to the bleaching below $350 \mathrm{~nm}$. The reaction of DFX with $\cdot \mathrm{OH}$ may occur through different ways. One is through redox reaction with the formation of DFX radical cation. Second is through addition reaction with the formation of addition products. The last one is through hydrogen abstraction reaction with formation of DFX neutral radical (reactions (13)-(15)). Because of a broad band observed only, we did not confirm the exact ascription of the broad band in the transient spectra of DFX, which may be attributed to the cation radical product or the addition product or the hydrogen abstraction product.

Considering that the $\lambda_{\max }$ of $\cdot \mathrm{OH}$ is the deep UV and DFX has a rather intensive absorption below $350 \mathrm{~nm}$, it was inpossible to measure the rate constant of the reaction between DFX and $\cdot \mathrm{OH}$ from the decay of $\cdot \mathrm{OH}$. Different bands were observed in the transient spectra and the reactions of DFX with $\cdot \mathrm{OH}$ may occur through different ways. Therefore, we chose different wavelengths to determine the rate constants by following the formation bleaching and the formations of different transient species (listed in Table 1). Considering that the bleaching at $340 \mathrm{~nm}$ may partly

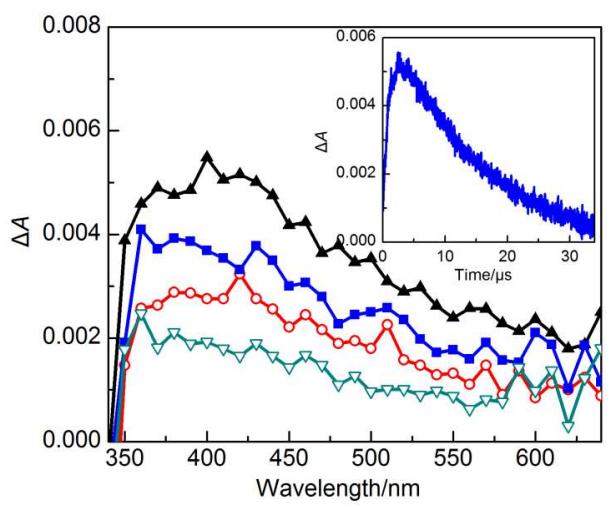

Fig.10 Transient difference absorption spectra observed at $0.5 \mu \mathrm{s}$ $(-\Delta-), 1 \mu s(-\circ-), 5 \mu s(-\varpi-), 20 \mu s(-\nabla-)$ after pulse radiolysis subjecting a nitrous oxide saturated aqueous solution of $1.0 \times 10^{-4}$ $\mathrm{mol} \cdot \mathrm{L}^{-1} \mathrm{DFX}$ in $5 \times 10^{-3} \mathrm{~mol} \cdot \mathrm{L}^{-1}$ phosphate buffer (pH 7.17)

Inset shows the time profile at $440 \mathrm{~nm}$ of $1.0 \times 10^{-4} \mathrm{~mol} \cdot \mathrm{L}^{-1} \mathrm{DFX}$ aqueous solution in $5 \times 10^{-3} \mathrm{~mol} \cdot \mathrm{L}^{-1}$ phosphate buffer $(\mathrm{pH} 7.17)$.

Table 1 Rate constants $(k)$ of DFX with $\cdot \mathrm{OH}$ in neutral aqueous solution

\begin{tabular}{ccccc}
\hline \multirow{2}{*}{ Compound } & \multicolumn{4}{c}{$k /\left(\mathrm{dm}^{3} \cdot \mathrm{mol}^{-1} \cdot \mathrm{s}^{-1}\right)$} \\
\cline { 2 - 5 } & $340 \mathrm{~nm}$ & $380 \mathrm{~nm}$ & $440 \mathrm{~nm}$ & $500 \mathrm{~nm}$ \\
\hline DFX & $4.8 \times 10^{9}$ & $9.8 \times 10^{9}$ & $1.3 \times 10^{10}$ & $1.1 \times 10^{10}$ \\
\hline
\end{tabular}

contain contributions of some transient species, the rate constants were determined by following the bleaching at $340 \mathrm{~nm}$. It was shown that the rate constants at $340 \mathrm{~nm}$ were smaller than those determined at other wavelengths. However, the values of the rate constants determined at 380, 440, and $500 \mathrm{~nm}$ were very close. Therefore, although it is still not exact that the ratios of the three different reaction ways, the rate constant of $\mathrm{DFX}$ with $\cdot \mathrm{OH}$ was estimated to be $1.0 \times 10^{10} \mathrm{dm}^{3} \cdot \mathrm{mol}^{-1} \cdot \mathrm{s}^{-1}$, and is nearly diffusioncontrolled.

\section{Conclusions}

Two conclusions from this work: the first one refers to the identification of the primary photo-processes of DFX in aqueous solution by $355 \mathrm{~nm}$ laser flash photolysis. The basic properties of DFX were determined including the triplet energy of ${ }^{3} \mathrm{DFX}^{*}$, the molar absorption coefficient of ${ }^{3} \mathrm{DFX}^{*}$, the quantum yield of photoionization, and the quantum yield of ${ }^{3} \mathrm{DFX}$. The second one refers to the radicals produced in the pulse radiolysis, which may lead to the phototoxic reaction of the drug. DFX is likely to find its way into human via these species even though the drug is used only for veterinary purpose. Few clinical of photosensitivity of DFX was reported because of the difficulties in associating any photosensitivity induced by the drug taken in via food chain. So it is important to study the photochemical properties since DFX as large quantities of aquaculture species is consumed by the animal beings.

\section{References}

(1) Condorelli, G.; De Guidi, G.; Giuffrida, S.; Sortino, S.; Chillemi, R.; Sciuto, S. Photochem. Photobiol. 1999, 70, 280.

(2) Martinez, L.; Chignell, C. F. J. Photochem. Photobiol. B 1998, 45, 51. doi: 10.1016/S1011-1344(98)00160-2

(3) Klecak, G.; Urbach, F.; Urwyler, H. J. Photochem. Photobiol. B 1997, 37, 174. doi: 10.1016/S1011-1344(96)07424-6

(4) Martinez, L. J.; Sik, R. H.; Chignell, C. F. Photochem. Photobiol. 1998, 67, 399. doi: 10.1111/php.1998.67.issue-4

(5) Jechalke, S.; Focks, A.; Rosendahl, I.; Groeneweg, J.; Siemens, J.; Heuer, H.; Smalla, K. Fems Microbiol. Ecol. 2014, 87, 78. doi: 10.1111/1574-6941.12191

(6) Domagala, J. M. J. Antimicrob. Chemoth. 1994, 33, 685. doi: $10.1093 / \mathrm{jac} / 33.4 .685$

(7) Matsumoto, M.; Kojima, K.; Nagano, H.; Matsubara, S.; Yokota, T. Antimicrob. Agents Chemother. 1992, 36, 1715. doi: 10.1128/AAC.36.8.1715

(8) Fasani, E.; Profumo, A.; Albini, A. Photochem. Photobiol. 1998, 68, 666. doi: 10.1111/php.1998.68.issue-5

(9) Monti, S.; Sortino, S.; Fasani, E.; Albini, A. Chem. Eur. J. 2001, 7,2185 .

(10) Li, H. X.; Liu, Y. C.; Tang, R. Z.; Zhang, P.; Wang, W. F. Sci. China Chem. 2012, 55, 1358.

(11) Liu, Y. C.; Zhang, P.; Li, H. X.; Tang, R. Z.; Cui, R. R.; Wang, W. J. Photochem. Photobiol. B 2013, 118, 58. doi: 10.1016/j. 
jphotobiol.2012.11.002

(12) Li, H. X.; Zhang, P.; Liu, Y. C.; Tang, R. Z.; Xing, Z. G.; Yao, S. D.; Fu, H. Y.; Wang, W. F. Rad. Phys. Chem. 2012, 81, 40. doi: 10.1016/j.radphyschem.2011.09.005

(13) Ismail, M. Vet. Res. Commun. 2007, 31, 467. doi: 10.1007/ s11259-006-3464-4

(14) Inui, T.; Taira, T.; Matsushita, T.; Endo, T. Xenobiotica 1998, 28, 887. doi: $10.1080 / 004982598239128$

(15) Guo, J. B.; Ostermann, A.; Siemens, J.; Dong, R. J.; Clemens, J. Waste Manage. 2012, 32, 131. doi: 10.1016/j. wasman.2011.07.031

(16) Sun, M.; Li, J.; Gai, C. L.; Chang, Z. Q.; Li, J. T.; Zhao, F. Z. J. Vet. Pharmacol. Ther. 2014, 37, 186. doi: 10.1111/ jvp.2014.37.issue-2

(17) Drlica, K.; Zhao, X. L. Microbiol. Mol. Biol. Rev. 1997, 61, 377.

(18) Walker, R. D. Aust. Vet. J. 2000, 78, 84. doi: 10.1111/j.17510813.2000.tb10528.x

(19) Cao, H. P.; Zhang, H. X.; He, S.; Zheng, W. D.; Yang, X. L. Isr. J. Aquacult-Bamid 2013, 65, 896.

(20) Frazier, D. L.; Thompson, L.; Trettien, A.; Evans, E. I. J. Vet. Pharmacol. Ther. 2000, 23, 293. doi: 10.1046/j.13652885.2000.00285.x

(21) Atef, M.; El-Banna, H. A.; Abd El-Aty, A. M.; Goudah, A. Deut Tierarztl. Woch. 2002, 109, 320.

(22) Heinen, E. J. Vet. Pharmacol. Ther. 2002, 25, 1. doi: 10.1046/ j.1365-2885.2002.00381.x

(23) Abd El-Aty, A. M.; Goudah, A.; Ismail, M.; Shimoda, M. Vet. Res. Commun. 2005, 29, 297.

(24) Adams, A. R.; Haines, G. R.; Brown, M. P.; Gronwall, R.; Merritt, K. Can. J. Vet. Res. 2005, 69, 229.

(25) Ding, F. K.; Cao, J. Y.; Ma, L. B.; Pan, Q. S.; Fang, Z. P.; Lu, X. C. Aquaculture 2006, 256, 121.

(26) Lian, N.; Zhao, H. C.; Sun, C. Y.; Jin, L. P.; Zhang, Z. L.; Zheng, Y. Z. Chem. J. Chin. Univ. 2002, 23, 564. [连宁, 赵 慧春, 孙春燕, 金林培, 张仲伦, 郑雁珍. 高等学校化学学报, 2002, 23, 564.]
(27) Zuo, Z. H.; Yao, S. D.; Luo, J. A.; Wang, W. F.; Zhang, J. S.; Lin, N. Y. J. Photochem. Photobiol. B 1992, 15, 215. doi: 10.1016/1011-1344(92)85125-E

(28) Yao, S. D.; Sheng, S. G.; Cai, J. H.; Zhang, J. S.; Lin, N. Y. Radiat. Phys. Chem. 1995, 46, 105. doi: 10.1016/0969-806X(94) 00120-9

(29) Navaratnam, S.; Claridge, J. Photochem. Photobiol. 2000, 72, 283. doi: 10.1562/0031-8655(2000)072<0283:PPPOO $>2.0 . C O ; 2$

(30) Sortino, S.; De Guidi, G.; Giuffrida, S.; Monti, S.; Velardita, A. Photochem. Photobiol. 1998, 67, 167.

(31) Lorenzo, F.; Navaratnam, S.; Allen, N. S. J. Am. Chem. Soc. 2008, 130, 12238. doi: 10.1021/ja8044713

(32) Lorenzo, F.; Navaratnam, S.; Edge, R.; Allen, N. S. Photochem. Photobiol. 2008, 84, 1118. doi: 10.1111/php.2008.84.issue-5

(33) Fasani, E.; Negra, F. F. B.; Mella, M.; Monti, S.; Albini, A. J. Org. Chem. 1999, 64, 5388. doi: 10.1021/jo982456t

(34) Zhang, P.; Li, H. X.; Yao, S. D.; Wang, W. F. Sci. China Chem. 2014, 57, 409. doi: 10.1007/s11426-013-4986-6

(35) Buxton, G. V.; Greenstock, C. L.; Helman, W. P.; Ross, A. B. J. Phys. Chem. Ref. Data 1988, 17, 513. doi: 10.1063/1.555805

(36) Martinez, L. J.; Scaiano, J. C. Photochem. Photobiol. 1998, 68, 646. doi: 10.1111/php.1998.68.issue-5

(37) Sandros, K.; Backstrom, H. L. J. Acta Chim. Scand. 1962, 16 , 958. doi: 10.3891/acta.chem.scand.16-0958

(38) Sandros, K. Acta Chim. Scand. 1964, 18, 2355. doi: 10.3891/ acta.chem.scand.18-2355

(39) Gorman, A. A.; Hamblett, I.; Jensen, N. H. Chem. Phys. Lett. 1984, 111, 293. doi: 10.1016/0009-2614(84)85509-8

(40) Lhiaubet-Vallet, V.; Cuquerella, M. C.; Castell, J. V.; Bosca, F.; Miranda, M. A. J. Phys. Chem. B 2007, 111, 7409. doi: 10.1021/ jp070167f

(41) Lorenzo, F.; Navaratnam, S.; Edge, R.; Allen, N. S. Photochem. Photobiol. 2009, 85, 886. doi: 10.1111/php.2009.85.issue-4

(42) Monti, S.; Sortino, S. Photochem. Photobiol. Sci. 2002, 1, 877.

(43) Bensasson, R. V.; Gramain, J. C. J. Chem. Soc. Faraday Trans. 1980, 76, 1801. doi: 10.1039/f19807601801 